А.В. Тристан ${ }^{1}$, I.М. Крижанівський ${ }^{1}$, С.А. Мельник ${ }^{2}$, Є.М. Горбут ${ }^{2}$

${ }^{1}$ Харківський національний університет Повітряних Сил ім. І. Кожедуба, Харків

${ }^{2}$ Національний університет оборони України ім. I. Черняховського, Київ

\title{
МОДЕЛЬ ОЦІНЮВАННЯ ІНФОРМАЦІЙНИХ МОЖЛИВОСТЕЙ ОРГАНІВ УПРАВЛІННЯ РОЗВІДКОЮ
}

Побудована модель очінювання інформачійних можливостей органів управління розвідкою. В основу моделі оцінювання інформаційних можливостей органу управління розвідкою покладений системний підхід, як методологію дослідження складних систем та математичні моделі теорії масового обслуговування. Розвідувальна інформація, яка надходить до інформаџійних систем у вигляді інформаційних документів (термінових, позачергових), розглядається як потоки інформації з певною інтенсивністю (щільністю), які потрібно зібрати, обробити і розподілити за визначений час. Отримано залежності між характеристиками (параметрами) потоків розвідувальної інформації, максимальним часом їх обробки, чисельністю особового складу та ймовірністю обробки інформації.

Ключові слова: інформаџійні можливості, органи управління розвідкою, потоки інформації, розвідувальна інформація, система оперативної розвідки.

\section{Вступ}

Постановка проблеми. Умови сучасної збройної боротьби, зокрема досвід, набутий під час проведення антитерористичної операції (АТО) та операції Об'єднаних сил (ООС) свідчить, що ефективність застосування сил і засобів розвідки залежить від ретельно організованої розвідувальноінформаційної діяльності органів управління розвідкою (ОУР) всіх рівнів. Обмеження в часі, просторовий розмах операцій (ведення бойових дій), використання нових видів зброї, в тому числі високоточної, висока мобільність військ та динамічність бойових дій вимагають від органу управління оперативнотактичного угруповання військ (ОТУВ) підготовки рішень, обгрунтування яких спирається на великі обсяги розвідувальної інформації та об’єктивної оцінки їх якості.

Виникає невідповідність між вимогами до оперативності та повноти обробки розвідувальної інформації органами управління розвідкою й чисельним складом даного органу.

Обгрунтування чисельності особового складу, що обробляє розвідувальну інформацію (PI), здійснюється шляхом моделювання з використанням теорії масового обслуговування.

Дані розрахунки достатньо складні та потребують автоматизації, отже необхідно розробити модель оцінювання інформаційних можливостей органів управління розвідкою з застосуванням сучасних інформаційних технологій.

Аналіз останніх досліджень і публікацій. Питання моделювання та визначення ефективності функціонування складних систем, показників їх оцін- ки, вхідних та вихідних даних, необхідних для моделювання, викладено достатньо повно в [1-6].

В основу моделі оцінювання інформаційних можливостей органу управління розвідкою можна покласти системний підхід, як методологію дослідження складних систем [6] та математичні моделі теорії масового обслуговування [7-9]. Реалізація даних моделей виконується 3 використанням сучасних мов програмування [10]. Отримані прикладні програми можуть бути застосовані в системах підтримки прийняття рішень (СППР) автоматизованих систем управління різних рівнів [11].

Метою статті $\epsilon$ побудова моделі оцінювання інформаційних можливостей органів управління розвідкою.

\section{Виклад основного матеріалу}

Метою моделювання є отримання залежностей між характеристиками (параметрами) потоків PI, максимальним часом їх обробки, чисельністю особового складу та ймовірністю обробки інформації.

Відповідно до системного підходу [6] в ході дослідження функціонування складних систем здійснюється їх декомпозиція і декомпозиція процесів їх функціонування, що дає можливість визначити їх ієрархічно-функціональну структуру. Матеріальною основою підсистеми інформації $є$ особовий склад 3 відповідним комплектом засобів зв'язку та автоматизації. Основним призначенням підсистеми інформації ОУР ОТУВ є розвідувально-інформаційна діяльність (РІД) змістом якої є збір, обробка та доведення РI [12].

На кожному ієрархічному рівні є один елемент інформації або їх сукупність. Кожен елемент інфор- 
мації у складі підсистеми інформації системи оперативної розвідки (СОР), як правило, має один або декілька каналів надходження РІ, яка надходить від підпорядкованих розвідувальних підрозділів (розвідувальних органів), елементів і підсистем інформації свого, вищого і нижчого рівнів та взаємодіючих, які є джерелами інформації. Під джерелом розуміють будь-яку систему, що дає повідомлення чи містить інформацію, призначену для передавання. Джерелом інформації також може бути об'єкт (явище), що вивчають і який створює або поширює інформацію. Кожне джерело інформації в СОР надає відповідним інформаційним системам PI, яку збирають, обробляють і розподіляють у вигляді інформаційних документів (звітно-інформаційних, довідкових) [13]. Такі документи слід розглядати як заявки на обслуговування відповідно до теорії масового обслуговування [2; 7]. Кожному документу відповідає PI певного характеру і обсягу, кожен 3 них надходить до підсистеми інформації на входи відповідних елементів інформації СОР, хоча й у відповідні на кожному етапі функціонування, але все-таки у випадкові моменти часу. Можливо допустити, що кожен офіцер збирає PI з одного каналу іiі надходження у випадкові моменти часу і фіксує їі надходження. До обробки приймають максимальну кількість PI. Процес обробки PI є складним, оскільки пов'язаний з черговістю, своєчасністю та розподілом інформації. Черговість обробки РІ визначається іiі характеристиками: ступенем важливості й вірогідності (вірогідна, не вірогідна). За ознакою важливості РІ поділяється на особливо важливу і звичайну [13]. Насамперед обробляють особливо важливу i важливу PI, а потім - звичайну. Така черговість зумовлена кількістю особового складу і розподілом обов'язків між ними. Ступінь важливості PI визначає офіцер напрямку з моменту іiі надходження до інформаційної системи, а час визначення ступеня важливості PI порівняно із часом іiі подальшої обробки є на порядок менше. Ступінь вірогідності PI, тобто ступінь відповідності іiі змісту, дійсному стану, що характеризує обстановку, визначається джерелом, від якого надходить PI. Тому час обробки РI є визначальним у питанні своєчасності їі обробки і розподілу. Таким чином, потік РІ можна розглядати як два потоки, які потребують упорядкування або (в термінології теорії масового обслуговування [14]) пріоритетності в обслуговуванні.

Декомпозиція процесів функціонування елементів та підсистем інформації СОР на етапи і субетапи дає можливість визначити їх часову структуру. Встановлено, що процеси функціонування елементів і систем інформації доцільно ототожнювати 3 циклом РІД та періодами оновлення розвідувальної інформації. Залежно від періодичності оновлення розвідувальної інформації, узгоджують зусилля сил і засобів розвідки, враховуючи вимоги до терміновості інформації.

Органи розвідки подають РІ до відповідних інформаційних систем після виконання завдань розвідки, тобто протягом часу, який можна назвати випадковим. Підпорядковані, старші і взаємодіючі інформаційні системи подають РI до певних підсистем інформаційних систем відповідно до табелю термінових донесень, однак у випадкові моменти часу, тобто процес збору, обробки і розподілу PI можна розглядати, як випадковий.

Прийоми і методи моделювання функціонування елементів і підсистем дозволяють віднести їх до систем масового обслуговування (СМО), ефективність яких досліджується за допомогою математичних методів теорії масового обслуговування, тобто враховує динаміку подій. Характерною загальною особливістю цих методів є те, що вони відносяться не до поодиноких об'єктів (потоків), а до певної їх множини, що розосереджена у часі або просторі, тобто можна говорити про масове надходження об'єктів (потоків) до елементів і підсистем інформаційних систем, як складової частини СОР.

PI, яка надходить на елементи інформації у вигляді інформаційних документів (термінових, позачергових), розглядається як потоки інформації з певною інтенсивністю (щільністю), які потрібно зібрати, обробити і розподілити за визначений час. Як уже відмічалось, потоки заявок надходять у випадкові моменти часу. Потік заявок розглядається, як найпростіший, тобто вхідний потік РІ відповідає закону Пуассона (пуассонівський) і має такі властивості: дискретний (всі події в потоці можуть бути перераховані), однорідний (всі події - заявки в потоці одного типу), ординарний (одночасно не може відбуватись дві і більше подій), без післядії (кількість подій, що потрапляють на непересічні часові інтервали, не залежать одна від іншої), стаціонарний (середня кількість подій, що потрапляють в однакові за тривалістю інтервали часу в будь-якому місці осі часу - постійна). Граф будь-якої СМО будується за схемою Марківського випадкового процесу “загибелі і розмноження”, тобто процес збору, обробки і розподілу РІ пов'язаний із сусідніми прямим і зворотнім зв'язком [1]. Елементи і підсистеми інформаційної системи СОР доцільно розглядати як СМО 3 очікуванням. Обмеження накладаються на час очікування заявки в черзі, а також на кількість місць у черзі (заявка, яка не обслугована своєчасно і якісно, втрачає свою цінність частково або повністю). Здебільшого елементи і підсистеми інформаційної системи розглядають як СМO з перевагами (пріоритетами) на обслуговування.

Для вибору показників і критеріїв оцінки ефективності функціонування елементів і підсистем інформаційної системи СОР доцільно скористатися 
традиційними параметрами потоків CMO та їхніх станів [3-5]:

- $\lambda$ - інтенсивність (щільність) потоку (математичне сподівання або середня кількість заявок), які надходять до елементів і інформаційних систем в одиницю часу;

$-\lambda_{1}-$ інтенсивність потоків заявок особливо важливої і важливої PI;

$-\lambda_{2}-$ інтенсивність потоків заявок звичайної РI;

Характеристиками (параметрами) елементів i підсистем інформаційних систем доцільно вважати:

- $T_{\text {об }}$ - випадкову величину часу обслуговування однієї заявки одним каналом; значенням $T_{\text {об }}$ обчислюється як математичне сподівання (середній час) обслуговування однієї заявки одним каналом $m_{\text {toб }}=M\left(T_{\text {oб }}\right)$, а також параметр показового розподілу величини $T_{о б}$, який розглядається як інтенсивність (щільність) потоку (середня кількість) “обслуговування” заявок елементів і підсистем інформаційних систем в одиницю часу: $\mu=\frac{1}{m_{\text {toб }}}$;

- $T_{о ч}$ - випадкову величину часу очікування однієї заявки в черзі; по значенню $T_{о ч}$ обчислюється як математичне сподівання часу (середній час) очікування однієї заявки в черзі (системі) $m_{t o \varphi}=M\left(T_{O ч}\right)$, так і параметр показового розподілу величини $T_{о ч}$, який розглядається як інтенсивність (щільність) потоку (середня кількість) “уходу” заявок із каналу елементів і підсистем інформаційної системи в одиницю часу, що обумовлюється обмеженням на час перебування заявки у системі (“старіння" інформації);

$$
-v=\frac{1}{m_{\text {toч }}}-\text { величина, зворотна середньому }
$$

часу “уходу” заявок із каналу;

$-\alpha=\frac{\lambda}{\mu}-$ інтенсивність вхідного потоку заявок або інтенсивність заявок, які надходять до елементів і підсистем інформаційних систем за середній час обслуговування однієї заявки;

$-\beta=\frac{v}{\mu}-$ інтенсивність заявок, які не обслуговуються за середній час обслуговування однієї заявки;

- $n$ - кількість каналів у підсистемі інформаційної системи (що відповідає чисельному складу OУP);

- $s$ - кількість заявок, які стоять у черзі (знаходяться на обслуговуванні у підсистемі, елементі інформаційної системи);
- $m$-кількість місць у черзі на обслуговування.

Імовірнісними характеристиками (параметрами) станів (показниками оцінки ефективності функціонування) елементів та інформаційних систем СОР доцільно вважати такі:

- $P_{\text {об }}$ - ймовірність своєчасної і якісної обробки PI, яка надходить на елемент (інформаційноаналітичний підрозділ) інформаційної системи;

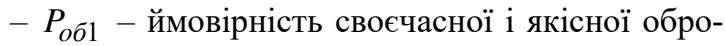
бки PI першого пріоритету, яка надходить на елемент (інформаційно-аналітичний підрозділ) інформаційної системи;

- $P_{\text {об2 }}$ - ймовірність своєчасної і якісної обробки РІ другого пріоритету, яка надходить на елемент (інформаційно-аналітичний підрозділ) інформаційної системи.

Розробимо математичну модель обробки PI в СОР. Розрахунок ймовірнісних показників проведено за формулами:

$$
\begin{gathered}
P_{\text {об }}=\frac{\beta}{\alpha} \times \frac{\frac{\alpha^{n}}{n !} \sum_{s=1}^{\infty} \frac{s \alpha^{s}}{\prod_{k=0}^{s}(n+m \beta)}}{\sum_{\text {oб1 }}^{n} \frac{\alpha^{k}}{k !}+\frac{\alpha^{n}}{n !} \sum_{s=1}^{\infty} \frac{\alpha^{s}}{\prod_{1}^{s}(n+m \beta)}} . \\
\sum_{k=0}^{n} \frac{\alpha_{1}^{k}}{k !}+\frac{\alpha_{1}^{n}}{n !} \sum_{s=1}^{\infty} \frac{\alpha_{1}^{n}}{n !} \sum_{s=1}^{\infty} \frac{s \alpha_{1}^{s}\left(n+m \beta_{1}\right)}{\prod_{m=1}^{s}\left(n+m \beta_{1}\right)} \\
P_{\text {об2 }}=\frac{\alpha P_{\text {oб }}-\alpha_{1} P_{\text {об1 }}}{\alpha_{2}} .
\end{gathered}
$$

Для проведення експериментального дослідження був розроблений програмний модуль в середовищі програмування високого рівня Delphi 7.

Програмний модуль забезпечує:

1. Введення вхідних даних моделі та перевірку іiі коректності.

2. Розрахунок статичних параметрів моделі.

3. Розрахунок динамічних параметрів і побудову графіків.

Математичний апарат різних типів СМО достатньо повно викладено в $[3 ; 4 ; 5]$.

Розрахунок показників оцінки ефективності елементів і підсистеми інформації в програмному модулі реалізовано відповідно обраної СМО [4].

Результати розрахунків ймовірностей обслуговування потоків PI, які надходять на входи елементів підсистем інформації наведено на рис. 1-4. 


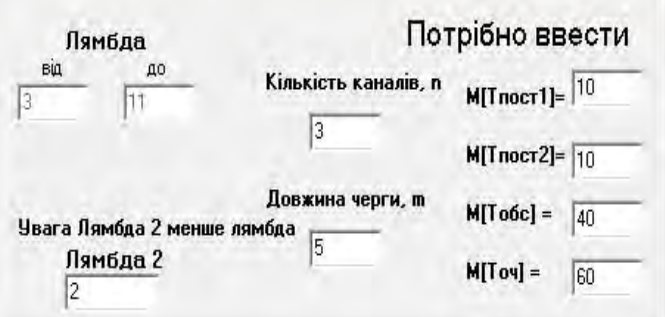

Розрахуеться автоматично
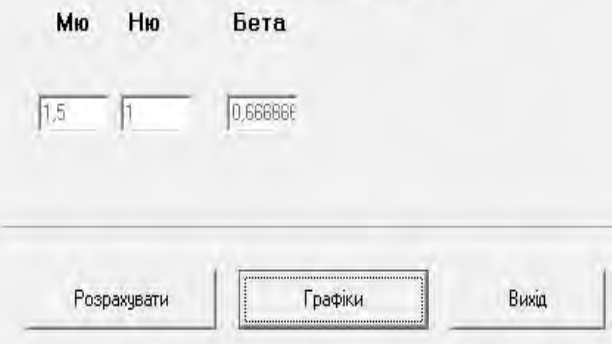

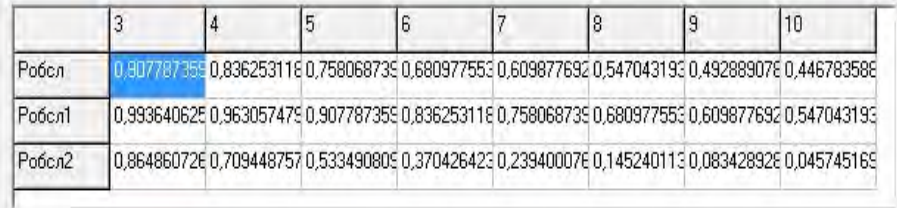

Ймовірність обсплуговування

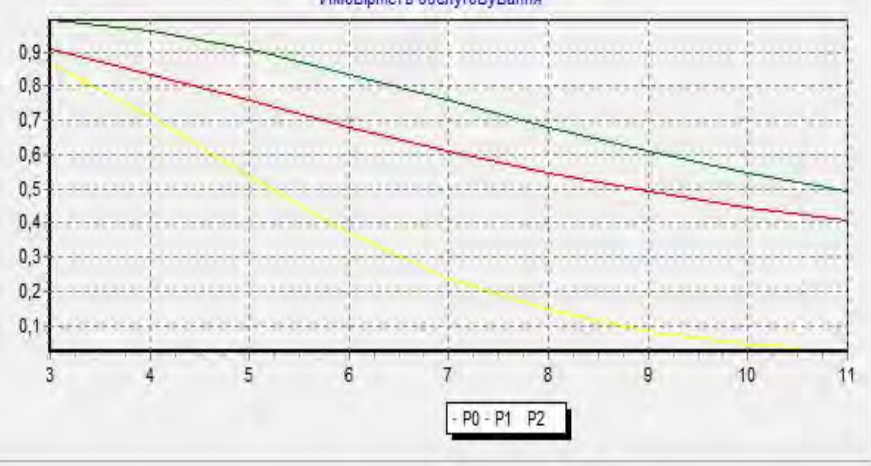

Рис. 1. Імовірність обслуговування потоків, які надходять на входи елементів підсистем інформації залежно від $\mu=1,5 ; \nu=1 ; \beta=0,6 ; n=3$
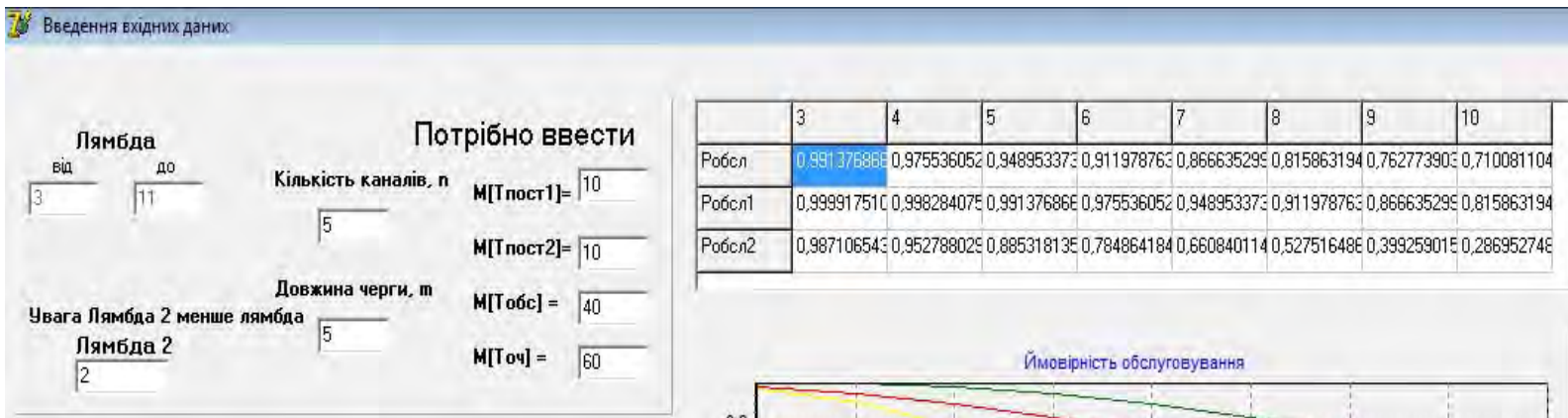

Розрахуеться автоматично
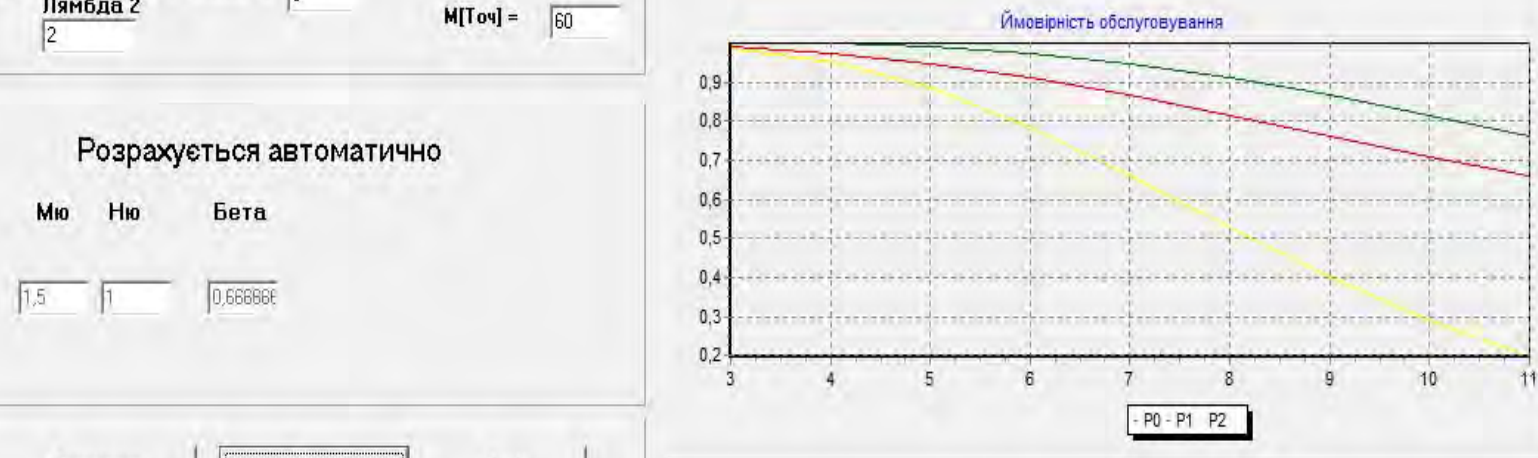

Розрахувати 1 Графіки

Рис. 2. Імовірність обслуговування потоків, які надходять на входи елементів підсистем інформації залежно від $\mu=1,5 ; \nu=1 ; \beta=0,6 ; n=5$

Отримані результати показують, що не враховуючи пріоритетність в обслуговуванні заявок, неможливо оцінити відмінності у своєчасності обробки і розподілу особливо важливої, важливої та звичайної PI, що $\epsilon$ неприпустимо в бойових умовах за досвідом ООС (АТО).

Дослідження ефективності функціонування елементів і підсистем інформації СОР за обраними показниками на підставі отриманих результатів по- казує залежність ймовірності своєчасної і якісної обробки РІ ( $\left.P_{\text {об }}\right)$ від:

- кількості каналів (n) у інформаційній системі, тобто від кількості офіцерів інформаторів;

- часу обслуговування однієї заявки одним каналом $\left(T_{о б}\right)$ у інформаційній системі, тобто швидкість обробки одного розвідувального донесення одним офіцером інформатором за одиницю часу. 


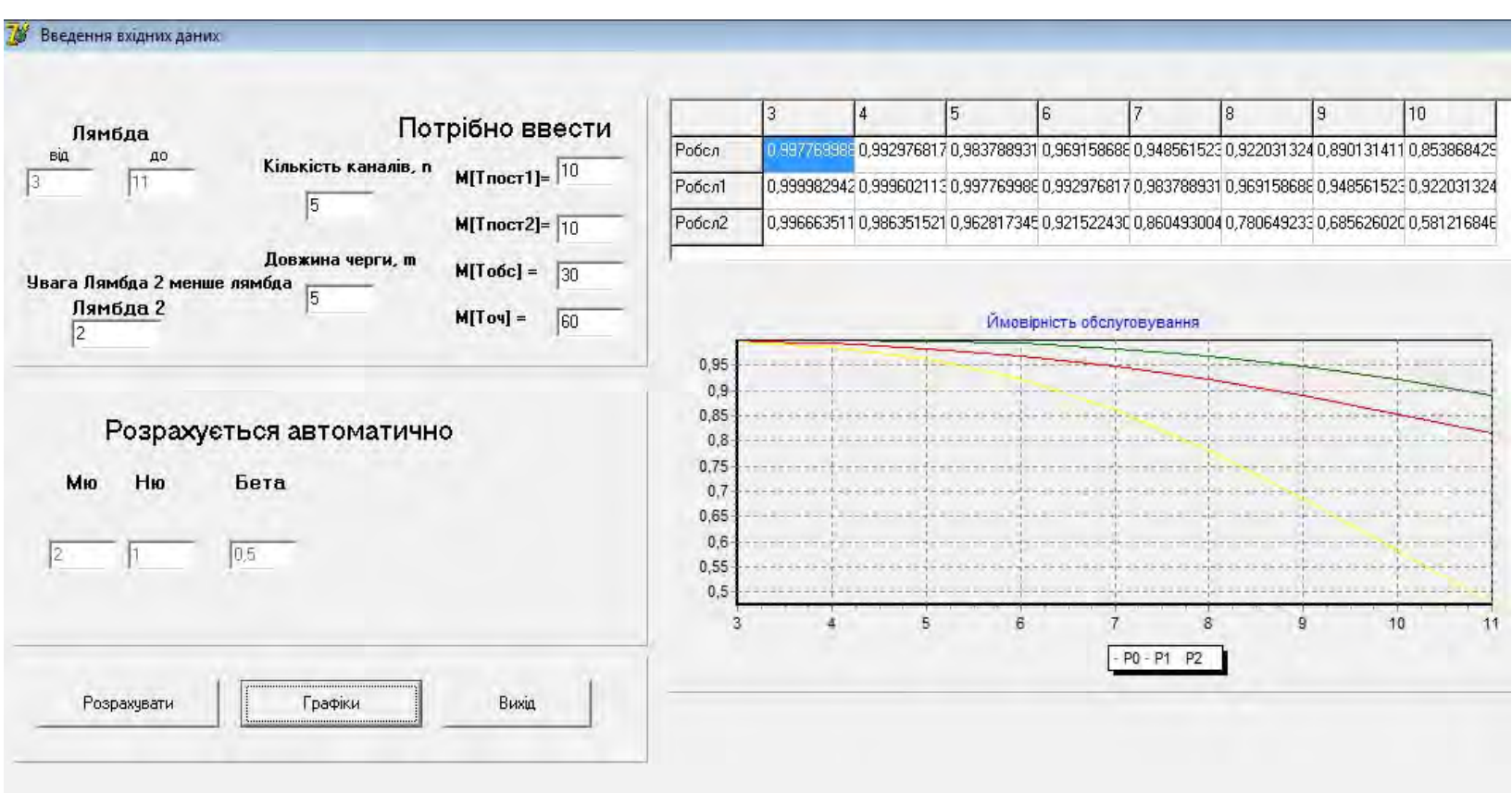

Рис. 3. Імовірність обслуговування потоків, які надходять на входи елементів підсистем інформації залежно від $\mu=2 ; v=1 ; \beta=0.5 ; n=5$

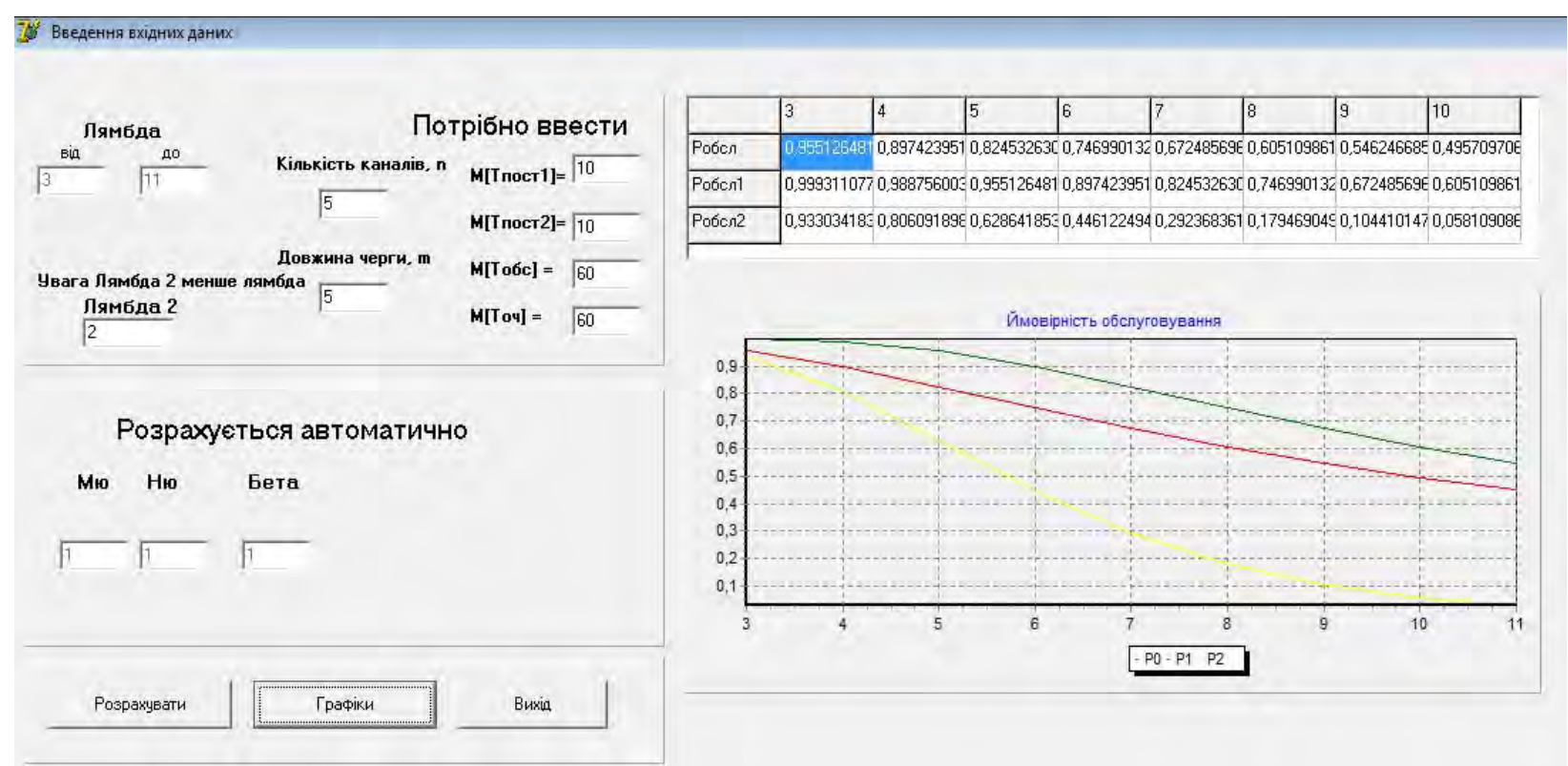

Рис. 4. Імовірність обслуговування потоків, які надходять на входи елементів підсистем інформації залежно від $\mu=1 ; v=1 ; \beta=1 ; n=5$

Дані залежності показують наскільки в сучасних умовах ведення бойових дій вирішальну роль відіграють автоматизація процесів збору, обробки і розподілу PI, оптимальна організаційно-штатна структура ОУР з підготовленими офіцерами інформаторами. Аналіз отриманих результатів дозволяє зробити висновки, що використання апарату СМО для моделювання й оцінювання ефективності інформаційних можливостей ОУР дозволяє встановити закономірності його функціонування, визначити залежності і на цій підставі обгрунтувати рекомендації щодо підвищення ефективності РІД.
Метод моделювання функціонування інформаційних систем для ОУР, який пропонується є узагальненим.

\section{Висновки}

В статті побудована модель оцінювання інформаційних можливостей органів управління розвідкою. За результатами роботи обгрунтовано прийоми, принципи і методи та раціональний загальний порядок оцінювання інформаційних можливостей ОУР. Розроблений програмний модуль в середовищі програмування високого рівня Delphi 7 дає змогу 
отримати результати моделювання, які можливо використати для обгрунтування рекомендацій підвищення ефективності функціонування ОУР та їх чисельності. Це дозволяє в логічній послідовності провести оцінювання інформаційних можливостей ОУР за обраними показниками та запропонувати рекомендації для підвищення ефективності РІД в ОУР.

\section{Список літератури}

1. Пермяков О.Ю. Використання інформаційних технологій та застосування космічних систем в інтересах військ (сил) / О.Ю. Пермяков, В.Г. Солонніков, Ю.Б. Прибилєв. - К.: НУОУ, 2014. - 208 с.

2. Гнеденко Б.В. Введение в теорию массового обслуживания / Б.В. Гнеденко, И.Н. Коваленко. - М.: Наука, 1987. $-336 \mathrm{c}$.

3. Боев В. Моделирование систем. Инструментальные средства GPSS World. / В. Боев. - СПб.: ВНV, 2012. - 368 с.

4. Сирота А.А. Компьютерное моделирование и оценка эффективности сложных систем / А.А. Сирота. - М.: Техносфера, 2006. - $280 \mathrm{c}$.

5. Шелухин О.И. Моделирование информационных систем / О.И. Шелухин. - М.: РиС, 2016. - 536 с.

6. Мірошніков О.П. Системний підхід при дослідженні функціонування систем оперативної розвідки / О.П. Мірошніков // Труди академії. - 2003. - № 48. - С. 60-65.

7. Карташевский В.Г. Основы теории массового обслуживания / В.Г. Карташевский. - М.: Радио и связь, 2006. - 108 с.

8. Ложковский А.Г. Моделирование многоканальной системы обслуживания с организацией очереди / А.Г. Ложковский, Н.С. Салманов, О.В. Вербанов // Восточно-европейский журнал передовых технологий. - 2007. - № 3 (27). - С. $72-76$.

9. Кениг Д. Методы теории массового обслуживания / Д. Кениг, Д. Штойян. - М.: Радио и Связь. - 1981. - 128 с.

10. Голицына О.Л. Программирование на языках высокого уровня / О.Л. Голицына, И.И. Попов. - М.: Форум, 2010. $-496 \mathrm{c}$.

11. Теорія прийняття рішень органами військового управління: монографія / В.І. Ткаченко, Г.А. Дробаха, С.Б. Смірнов, А.В. Тристан. - Х.: ХУПС, 2008. - 545 с.

12. ВСТ 01.101.004. Розвідувально-інформаційна діяльність. Терміни та визначення. - К., 2015. - 26 с.

13. Розвідувально-інформаційна та інформаційно-аналітична діяльність у системі воєнної розвідки. - К.: НУОУ, 2016. $-48 \mathrm{c}$.

14. Алгазинов Э.К. Анализ и компьютерное моделирование информационных процессов и систем / Э.К. Алгазинов, А.А. Сирота. - М.: Диалог-МИФИ, 2009. - 416 с.

\section{References}

1. Permiakov, O.Yu, Solonnikov, V.H. and Prybyliev, Yu.B. (2014), "Vykorystannia informatsiinykh tekhnolohii ta zastosuvannia kosmichnykh system $v$ interesakh viisk (syl)" [The use of information technology and the use of space systems in the interests of troops (forces)], NUOU, Kyiv, $208 \mathrm{p}$.

2. Hnedenko, B.V. and Kovalenko, Y.N. (1987), "Vvedenye v teoryiu massovoho obsluzhyvanyia" [Introduction to queuing theory], Nauka, Moscow, $336 \mathrm{p}$.

3. Boev, V. (2012), "Modelirovanie sistem. Instrumental'nye sredstva GPSS World" [Modeling systems. GPSS World Tools], BHV, St. Petersburg, 368 p.

4. Sirota, A.A. (2006), "Komp'yuternoe modelirovanie i otsenka effektivnosti slozhnykh system" [Computer modeling and performance evaluation of complex systems], Tehnosfera, Moscow, $280 \mathrm{p}$.

5. Shelukhin, O.I. (2016), "Modelirovanie informatsionnykh sistem" [Modeling Information Systems], RiS, Moscow, 536 p.

6. Miroshnikov, O.P. (2003), "Systemnyi pidkhid pry doslidzhenni funktsionuvannia system operatyvnoi rozvidky" [A systematic approach to the study of the functioning of operational intelligence systems], Academy Proceedings, No. 48, pp. 60-65.

7. Kartashevskii, V.G. (2006), "Osnovy teorii massovogo obsluzhivaniya" [The basics of queuing theory], Radio i svyaz, Moscow, 108 p.

8. Lozhkovskii, A.G., Salmanov, N.S. and Verbanov, O.V. (2007), "Modelirovanie mnogokanal'noi sistemy obsluzhivaniya s organizatsiei ocheredi" [Modeling a multi-channel queuing system], East-European Journal of Advanced Technology, No. 3(27), pp. 72-76.

9. Kenig, D. and Shtoiyan, D. (1981), "Metody teorii massovogo obsluzhivaniya” [Queuing theory methods], Radio i svyaz, Moscow, 128 p.

10. Golitsyna, O.L. and Popov, I.I. (2010), "Programmirovanie na yazykakh vysokogo urovnya" [High Level Programming], Forum, Moscow, $496 \mathrm{p}$.

11. Tkachenko, V.I., Drobakha, H.A., Smirnov, Ye.B. and Trystan, A.V. (2008), “Teoriia pryiniattia rishen orhanamy viiskovoho upravlinnia" [Theory of Decision Making by Military Agencies], HUPS, Kharkiv, 545 p.

12. Military Standard (2015), "01.101.004: 2015 (02) Rozviduvalno-informatsiina diialnist. Terminy ta vyznachennia" [01.101.004: 2015 (02) Intelligence and information activity. Terms and definitions], Kyiv, 26 p.

13. (2016), "Rozviduvalno-informatsiina ta informatsiino-analitychna diialnist u systemi voiennoi rozvidky" [Intelligence, information and analytical activities in the military intelligence system], NUOU, Kyiv, 48 p.

14. Algazinov, E.K. and Sirota, A.A. (2009), "Analiz i komp'yuternoe modelirovanie informatsionnykh protsessov i sistem" [Analysis and computer modeling of information processes and systems], Dialog-MIFI, Moscow, 416 p. 
Відомості про авторів:

\section{Тристан Андрій Вікторович}

доктор технічних наук старший науковий співробітник начальник науково-дослідного відділу

Харківського національного університету

Повітряних Сил ім. І. Кожедуба,

Харків, Україна

https://orcid.org/0000-0003-0494-8125

\section{Крижанівський Ігор Миколайович}

науковий співробітник Харківського національного

університету Повітряних Сил ім. І. Кожедуба,

Харків, Україна

https://orcid.org/0000-0001-9885-9232

\section{Мельник Сергій Анатолійович}

слухач Національного університету

оборони України ім. І. Черняховського,

Київ, Україна

https://orcid.org/0000-0001-7730-4211

\section{Горбут Свген Миколайович}

слухач Національного університету

оборони України ім. І. Черняховського,

Київ, Україна

https://orcid.org/0000-0002-9147-5698

\section{Information about the authors:}

\author{
Andrii Trystan \\ Doctor of Technical Sciences Senior Research \\ Chief of Scientific Research Department \\ of Ivan Kozhedub Kharkiv National \\ Air Force University, \\ Kharkiv, Ukraine \\ https://orcid.org/0000-0003-0494-8125
}

\author{
Ihor Kryzhanivskyi \\ Research Associate of Ivan Kozhedub Kharkiv \\ National Air Force University, \\ Kharkiv, Ukraine \\ https://orcid.org/0000-0001-9885-9232
}

\section{Sergii Melnyk}

Postgraduate Student of the National Defence University of Ukraine named after Ivan Cherniakhovskyi,

Kyiv, Ukraine

https://orcid.org/0000-0001-7730-4211

\section{Yevhen Horbut}

Postgraduate Student of the National Defence University of Ukraine named after Ivan Cherniakhovskyi,

Kyiv, Ukraine

https://orcid.org/0000-0002-9147-5698

\title{
МОДЕЛЬ ОЦЕНКИ ИНФОРМАЦИОННЫХ ВОЗМОЖНОСТЕЙ ОРГАНОВ УПРАВЛЕНИЯ РАЗВЕДКИ
}

\author{
А.В. Тристан, И.Н. Крыжановский, С.А. Мельник, Е.Н. Горбут
}

Разработана модель оценки информационных возможностей органов управления разведкой. В основу модели оченки информационных возможностей органа управления разведкой положен системный подход, как методологию исследования сложных систем и математические модели теории массового обслуживания. Разведывательная информация, поступающая к информачионным системам в виде информачионных документов (срочных, внеочередных), рассматривается как потоки информации с определенной интенсивностью (плотностью), которые нужно собрать, обработать и распределить за определенное время. Получены зависимости между характеристиками (параметрами) потоков разведывательной информации, максимальным временем их обработки, численностью личного состава и вероятностью обработки информации.

Ключевые слова: информачионные возможности, органы управления разведкой, потоки информации, разведывательная информация, система оперативной разведки.

\section{MODEL OF ASSESSMENT OF INFORMATION POSSIBILITIES OF INTELLIGENCE MANAGEMENT BODIES}

\section{A. Trystan, I. Kryzhanivskyi, S. Melnyk, Y. Horbut}

A model has been developed for assessing the information capabilities of intelligence agencies. The model of assessing the information capabilities of the intelligence control body is based on a systematic approach, as a methodology for the study of complex systems and mathematical models of queuing theory. Intelligence information coming to information systems in the form of information documents (urgent, extraordinary) is considered as information flows with a certain intensity (density), which must be collected, processed and distributed over a certain time. It is advisable to consider the elements and subsystems of the information system of the operational intelligence system as a queuing system with anticipation. Limitations are imposed on the waiting time of the application in the queue, as well as on the number of places in the queue, which is due to the fact that the application, not served timely and efficiently, loses its value partially or completely. Basically, the elements and subsystems of information are considered as a mass service system with advantages (priorities) for servicing. To select indicators and criteria for evaluating the effectiveness of the functioning of elements and information subsystems of the operational intelligence system, it is advisable to use the traditional parameters of the queuing system flows and their conditions. The characteristics (parameters) of the elements and subsystems of information systems were selected: a random value of the time it takes to service one application with one channel, a random value of the time it takes to wait for one application in the queue, the intensity of applications arriving at the elements and subsystems of information systems for the average hour of service of one application, the intensity of applications that are not served during the average hour of service of one application, the number of channels in the subsystem of the information system, the number of applications that are in the queue, the number of $m$ Art in the queue for service. The dependencies between the characteristics (parameters) of intelligence information flows, the maximum processing time, the number of personnel and the probability of information processing are obtained.

Keywords: information capabilities, intelligence control bodies, information flows, intelligence information, operational intelligence system. 